\title{
Effect of age of dairy cows on body composition changes throughout the lactation cycle as measured with deuteriated water
}

\author{
$R$ Vérité $^{1}, Y$ Chilliard $^{2}$ \\ 1 INRA, Station de Recherches sur la Vache Laitière, 35590 L'Hermitage; \\ ${ }^{2}$ INRA, Laboratoire de la Lactation, Theix, 63122 Saint-Genes Champanelle, France
}

The changes in body composition of Holstein cows during lactation of $(6+6)$ primiparous calving at 2 (P2) or 3 years (P3), with an average growth rate of 700 or $500 \mathrm{~g} / \mathrm{d}$ from birth, were compared with those of 10 multiparous cows (4 to 6 years old).

During 35 weeks from calving, the animals were fed high DM maize silage ad libitum, and concentrates: 1) at a constant and equal level for the first 6 months $(5.2 \mathrm{~kg} \mathrm{DM}$ for $P 2$ and $P 3$ or $6.0 \mathrm{~kg} \mathrm{DM}$ for $\mathrm{M}$ ); 2) decreasing according to requirements for the last 12 weeks; protein intake was continuously fitted to individual requirements. Milk yield (6 730 - $7370-8370 \mathrm{~kg}$ for P2 - P3 - M over 44 weeks) and feed intake were registered daily and body weight (BW) weekly. Body composition was measured from deuteriated water space (Chilliard and Robelin, 1983 ) on day 5 , and weeks $12 \pm 2$ and $35 \pm 2$ after calving.

At calving, total body lipids \% BW were higher in $\mathrm{P} 3(21.5 \%)$ than in P2 $(17.6 \%)$ and in $M(15.2 \%)$. In primiparous cows, decrease in mass of body lipids from calving to week 12 was only slightly less than in $M$ cows in agreement with calculated energy balance (EB). Their subsequent recovery was nil, but complete for $\mathrm{M}$-cows. The amount of body proteins hardly changed in early lactation or later, except for P2 cows $(+5.1 \mathrm{~kg})$ which were far from their mature size at calving (79\%). On a between-cow basis, in early lactation changes in protein mass (but not lipid mass) were correlated with BW changes; in midlactation, the 3 parameters were correlated but $\mathrm{BW}$ changes tended to have more lipid and less protein in $M$ than in $P$ cows. Primiparous cows can mobilize substantial amounts of lipids in early lactation, but after peak yield, a strong priority exists for protein deposition, which is all the more important as they are far from mature in size.

Chilliard Y, Robelin J (1983) Eur Assoc Anim Prod Publ 31, 2, 195-198

Table I. Body composition and energy balance during lactation.

\begin{tabular}{|c|c|c|c|c|c|c|c|c|c|}
\hline & \multicolumn{3}{|c|}{ At calving } & \multicolumn{3}{|c|}{ From wk 1 to 12} & \multicolumn{3}{|c|}{ From $w k 12$ to 35} \\
\hline & $\begin{array}{l}B W \\
(\mathrm{~kg})\end{array}$ & $\begin{array}{c}\text { Lipid } \\
(\mathrm{kg})\end{array}$ & $\begin{array}{c}\text { Protein } \\
(\mathrm{kg})\end{array}$ & $\begin{array}{c}E B \\
(F U)\end{array}$ & $\begin{array}{l}\text { Lipid } \\
(\mathrm{kg})\end{array}$ & $\begin{array}{l}\text { Protein } \\
\quad(\mathrm{kg})\end{array}$ & $\begin{array}{c}E B \\
(F U)\end{array}$ & $\begin{array}{l}\text { Lipid } \\
(\mathrm{kg})\end{array}$ & $\begin{array}{l}\text { Protein } \\
(\mathrm{kg})\end{array}$ \\
\hline $\begin{array}{l}P 2 \\
P 3 \\
M \\
r s d\end{array}$ & $\begin{array}{c}571 a \\
624 b \\
649 b \\
33\end{array}$ & $\begin{array}{r}96 a \\
129 b \\
99 a \\
25\end{array}$ & $\begin{array}{r}75 a \\
80 b \\
89 c \\
4.3\end{array}$ & $\begin{array}{r}-124 \\
-69 \\
-213 \\
100\end{array}$ & $\begin{array}{l}-24 \\
-24 \\
-33 \\
22.3\end{array}$ & $\begin{array}{r}-0.7 \\
1.1 \\
-0.6 \\
3.7\end{array}$ & $\begin{array}{r}217 a \\
21 b \\
104 a \\
104\end{array}$ & $\begin{array}{r}-2 a \\
-3 a \\
33 b \\
26.7\end{array}$ & $\begin{array}{l}5.1 a \\
0.9 b \\
1.9 b \\
3.5\end{array}$ \\
\hline
\end{tabular}

a, b : In the same column, means with different superscripts differ $(P<0.05)$. 